\title{
Development of Multidisciplinary Integrated Project-Based Learning Model To Improve Critical Thinking and Cooperation Skills
}

\author{
Harli Trisdiono ${ }^{1}$, Siswandari Siswandari ${ }^{2}$, Nunuk Suryani ${ }^{2}$, \\ Soetarno Joyoatmojo ${ }^{2}$ \\ ${ }^{1}$ Postgraduate Program, Science Education Department, Sebelas Maret University Surakarta \\ ${ }^{2}$ Faculty of Teacher Training and Education Sebelas Maret University, Surakarta \\ e-mail: trisdionoharli@gmail.com; siswandari@staff.uns.ac.id; nunuksuryani@fkip.uns.ac.id; strn_jo@yahoo.co.id.
}

\begin{abstract}
The development of a multidisciplinary integrated project-based learning model was carried out to answer the needs in elementary schools. Learning in elementary schools that uses thematic approaches needs to be managed well to improve learning effectiveness. This study uses a type of research and development. The development process uses the Gall, Gall \& Borg (2007) model. The preparation of guidelines and student book examples uses the steps of Dick, Carey, \& Carey (2009). The model developed is accompanied by derivative products, namely learning manuals and student book examples. Based on this study, learning manuals and student book examples can be used in multidisciplinary integrated project-based learning to improve critical thinking skills and student collaboration.
\end{abstract}

Keywords: project-based learning, integrated learning, multidisciplinary

\section{Introduction}

The quality of human resources is determined by the quality of education. Education that can support the improvement of the quality of human resources is effective, collaborative (Siripho, 2012), improving critical and creative thinking skills (Boyles \& College, 2012; Child \& Shaw, 2016). Effective education is education that is able to facilitate students according to their characteristics. Collaborative education involves schools / government, parents, and the community.

Critical thinking skills are the art of analyzing and evaluating (Serrat, 2010). As an art, critical thinking skills are influenced by the environment. Critical thinking is also a dimension where a person is sensitive to the conditions around him. Someone who thinks critically will think analytically and synthetically (Karakoc, 2016). Students who think critically, will analyze each information obtained, then synthesize the information. Critical thinking is also demonstrated by the ability to access information (Indrawatiningsih, 2018). Information increases knowledge and reduces uncertainty (Lipursari, 2013) and improves reasoning (Nahdi, 2015).

The ability to think critically, leads a person to act considerably and carefully (Haryani, 2011), explain reasons, and resolve problems (Indrawatiningsih, 2018). Someone who is full of consideration will not take a decision without considering the context of the problem at hand. Every decision taken is accompanied by a logical reason. Logically a reason can improve the quality of decisions taken. On the other hand, critical thinking skills can improve understanding of scientific concepts (Asmawati, 2015).

Increased understanding of the concepts of scientific disciplines (Asmawati, 2015) improves one's ability to connect subject matter with the real world (Kusmanto \& Marliyana, 2014). The ability to think critically in understanding the concepts of disciplines also increases the ability to connect between concepts (Afrilianto, 2012). Several studies were conducted to measure students' critical thinking skills. The results showed that students' skills in critical thinking were considered to be lacking (Haeruman, Rahayu, \& Ambarwati, 2017; Dianawati, Riastini, \& Pudjawan, 2017; Rachmawati, 2018; Susilowati, Sajidan, \& Ramli, 2017; Puspita \& Jatmiko, 2013). This is in line with the results of observations in the learning process. The results of the observation indicate that learning still often uses a single source of information. Learning students are still limited to using the textbook used. Utilization of other information 
sources such as the environment, the internet, enrichment books, and resource persons is still lacking. The ability to answer questions as one proof of critical thinking skills is also lacking. Not all students have the courage to answer questions.

Cooperation skills are one of the skills students must learn (Hapsari \& Yonata, 2014) because collaboration determines the success of the team (Adyarta, Hartono, \& Pramono, 2012). One successful team is influenced by the quality of cooperation. Collaboration occurs when two or more people work together to share resources to achieve a common goal. When cooperation occurs, each member is able to show the resources they have. Through collaboration, self-confidence and student interaction skills increase (Yulianti, Djatmika, \& Santoso, 2016). When students 'collaboration skills are good, the students' ability to adapt in the environment increases.

Research on the level of student collaboration was conducted by Khasanah et.al. (2018); Rosita \& Leonard (2013); and Suhardi (2013). The results of the study show that the level of student cooperation skills is still lacking. Observations on the learning process in several schools in the Special Region of Yogyakarta indicate that collaboration skills are still lacking. One proof that shows a lack of cooperation is when group work. During group work, work is often done by one or two group members. Based on this, it is necessary to develop critical thinking skills and cooperation. Steps in developing critical thinking skills and collaboration begin with the selection of learning methods that are applied (Snyder \& Snyder, 2008).

Project-based learning gives students the opportunity to share ideas, so they can brainstorm and solve problems together with supervision, guidance, and mentoring until they can build meaningful and useful projects. Project-based learning also provides opportunities for students to gain learning experience in order to actively develop knowledge. PBL is also challenging and motivating students, developing critical, analytical thinking skills and improving high-level thinking skills. PBL requires collaboration, communication, problem solving and selfdirected learning. PBL allows students to construct their knowledge based on the knowledge they already have (Bell, 2010); have a positive impact on achieving student material competencies (Quint \& Condliffe, 2018). Competence is achieved in three aspects, namely attitudes, knowledge and skills.

On aspects of attitude and skills, project-based learning is able to improve critical thinking skills and problem solving, enhance collaborative skills and resolve conflict and creative thinking (Fatimah, 2018; Rati, Kusmaryatni, \& Rediani, 2017). Through critical thinking skills the problem can be solved by collaborative and mitigating conflicts. Project-based learning also improves social skills; improve management, cooperation and precision skills while working in groups, and the opportunity to interact with friends and make new friends. Accuracy at group work is a skill that is needed so that group work can be effective and efficient. Through interaction with friends, learning can be done well and improve the ability of cooperation in mutual various resources.

Multidisciplinary learning is learning that combines several subjects (Helmane \& Briska, 2017). Each subject contributes material that is integrated into one material entity. Multidisciplinary learning is incorporated into a theme or topic (Murfiah, 2017). Themes that are built form harmony between material in several subjects. Achieving these three domains because integrated multidisciplinary learning is designed within the framework provides opportunities for students to face real world challenges (Alghamdi, 2017).

The study of the relationship between project-based learning and critical thinking skills and collaboration is carried out by several researchers. Rahmawati et.al. (2018), Effendy (2017), Jamaludin (2017), and Insyasiska, Zubaidah, \& Susilo (2015) found that project-based learning can improve students' critical thinking skills. On aspects of attitude and skills, projectbased learning is able to improve critical thinking skills and problem solving, enhance collaborative skills and resolve conflicts and creative thinking (Fatimah, 2018; Rati, Kusmaryatni \& Rediani, 2017). Project-based learning can also enhance collaboration skills. Adri \& Istyawati (2013), Lestari, Suarni, \& Antara (2016), and Miftari (2014) in their research found that project-based learning can enhance collaboration.

Preliminary studies as empirical studies and fact-finding are conducted to get support in formulating problems. The study was conducted with 52 research subjects. The process of 
understanding the needs of model development is done by analyzing the implementation plan of learning, the learning process, and the assessment process. Analysis of the learning implementation plan prepared by elementary school teachers produces conclusions: 1) Indicators and learning objectives formulated in the same concept, Teachers still have difficulty in distinguishing between indicators and learning objectives; 2) Indicators and learning objectives still refer to teaching material, there has not yet been an explicit attainment of attitudes and skills; 3) Teachers tend to use direct learning methods namely lectures and demonstrations.

Analysis of assessment planning indicates that the assessment is carried out focusing on learning outcomes, and tends to the domain of knowledge. Assessment planning has not targeted the process assessment, namely the assessment of student activities as a process to achieve competency attitudes, knowledge, and skills. Assessment in the realm of knowledge still tends to memorize yet facilitate students to think high-level in accordance with the taxonomy of learning developed by Bloom. The results of the Subagia \& Wiratma (2016) study show that the making of instruments for assessing student attitudes and tasks is not optimal. If this is not done, students are not ready to face the challenges faced (Wang, Lavonen, \& Tirri, 2018).

Observations on student activities provide the fact that students tend to listen, the use of learning media tends to be very minimal, and only uses textbooks and student worksheets. The use of communication information technology media tends to only display slides. Teacher mastery of the learning model or method that activates students is still lacking. The lack of teacher competence is indicated by the use of monotonous learning models or methods that tend to focus on mastering the realm of knowledge. Students are taught subject matter with a single subject approach, without knowing meaningfulness in life.

The results of interviews with teachers related to the assessment of critical thinking skills, and collaboration showed that: 1 ) as many as $60 \%$ of teachers have not made measurements of student character development, this is supported by the results of research by Astriyandi, Chotimah, \& Faisal, (2016) of $53,2 \%$ of teachers have not carried out an attitude assessment; 2) Observation of teachers on students' critical thinking skills indicated by the ability to ask questions, willingness to question, and answer questions with different answers but in the context of the content of teaching material is still lacking; 3 ) The ability of cooperation is still very weak. The results of Zuhera, Habibah, \& Mislinawati (2017) research show that teachers still have difficulty in giving attitude assessment. Difficulties are experienced especially in determining observable symptoms of critical thinking skills and collaboration.

A review of the teacher's book shows that the teacher's book is not sufficient. The teacher's book in implementing the curriculum is inadequate because there are many learning activities that do not have good guidelines. The assessment process carried out is still unfocused, giving less meaning to those observed, developed, and trained to provide feedback to students in developing themselves. The analysis of the teacher's book results that the implementation patterns of integrated thematic learning are summarized in themes and subthemes. The theme is divided into three sub-themes which are completed in three weeks. The fourth week is used to apply between sub-themes in student project learning titles. The results of the analysis show that what is meant by "project" tends to be in the form of activity-based learning. Most projects (90\%) end with exhibition activities. The results of the analysis of the teacher's book are deepened by interviews and observation of learning.

The results of interviews with teachers, observations of the learning process, analysis of the assessment process, analysis of plans for implementing learning, analysis of student books and books for elementary school grade IV teachers concluded: 1) Learning tends to use subjects focused on the realm of knowledge; 2) The assessment process places more emphasis on evaluating results; 3) Development of the domain of attitudes and skills has not been supported by monitoring; 4) There is no emphasis on skills and skills developed in the learning and monitoring process; 5) The development of attitudes and skills is assumed to be resolved at one time learning (one day) and has not focused on developing the same attitudes and skills at one particular time which is considered sufficient and observe all students; and 6) 
Guidelines needed by teachers in implementing one of the suggested learning models, namely project-based learning, not operational.

Based on these studies, there are gaps between the theoretical level of the process and the learning objectives with the practice of learning, planning, process, and evaluation of learning. Monitoring of the achievement of critical thinking skills and collaboration is not yet operational. Based on this background, it is necessary to develop a learning model that can accommodate the development of attitudes, mastery of knowledge competencies, and development of skills / skills. Specifically, the development of critical thinking skills and collaboration for elementary school students that are in accordance with the Indonesian context. One learning model that can facilitate the achievement of this goal is multidisciplinary integrated project-based learning.

\section{Method}

The research conducted is research and development. The selection of this type of research is based on the objectives to be achieved, namely developing a product in the form of a learning model with derivative products, namely learning guides and examples of student books. The flow of research used is presented in figure 1.

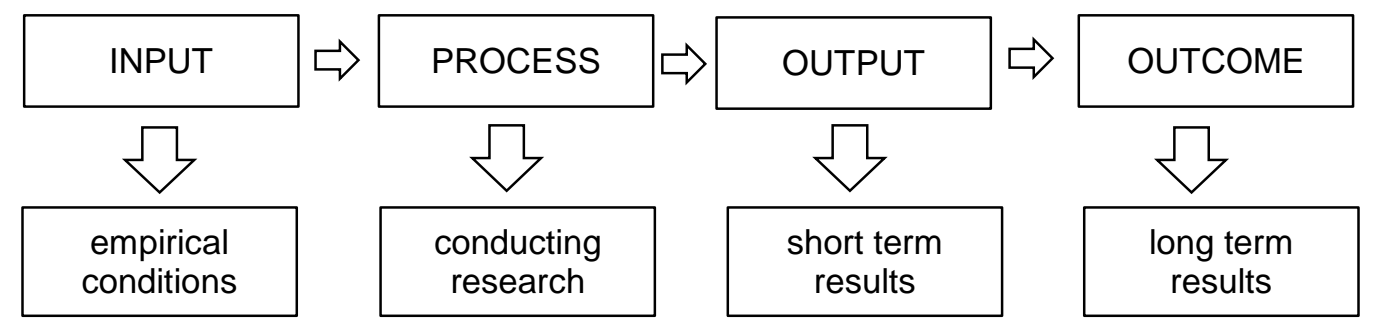

Figure 1. Research Flow

Development is carried out by adopting research and development methods proposed by Gall, Gall \& Borg (2007). The development step proposed by Gall, Gall \& Borg (2007) was adapted into three main stages of research and development as follows: 1) preliminary study phase; 2) the model development stage; and 3) the testing phase of model effectiveness. The development steps taken as a result of adaptation are as follows: 1. Preliminary Study Phase: 1) Literature Study; 2) Study of Documents; 3) Field Study. 2. Stage of Model Development: 4) Initial draft (Dick, Carey, \& Carey, 2009); 5) Expert Assessment; 6) Model Revision; 7) Oneon-one Tests; 8) Model Revision; 9) Limited trials; 10) Model Revision; 11) Large-scale trials; 12) Revisions; 3. The stage of testing the effectiveness of the model; 13) Test of Model Effectiveness; 14) Dissemination. This article describes the stages of developing the model from the development of the initial draft to expert assessment or validation.

Data and information obtained from preliminary studies are used as a basis in implementing model development. The development steps are presented in Table 1. as follows:

Table 1. Development Steps

\begin{tabular}{lllll}
\hline $\begin{array}{c}\text { Development } \\
\text { steps }\end{array}$ & \multicolumn{1}{c}{ Aim } & Method & Data source & $\begin{array}{c}\text { Data } \\
\text { processing }\end{array}$ \\
\hline 1. Initial draft & $\begin{array}{l}\text { Develop a } \\
\text { multidisciplinary } \\
\text { integrated project } \\
\text { based learning model }\end{array}$ & questionnaire & & \\
2. Expert & $\begin{array}{l}\text { Get a feedback on } \\
\text { readability models }\end{array}$ & $\begin{array}{l}\text { Educational } \\
\text { technology } \\
\text { experts, learning } \\
\text { media experts }\end{array}$ & $\begin{array}{l}\text { Qualitative } \\
\text { and } \\
\text { quantitative }\end{array}$ \\
\hline
\end{tabular}

\section{Results and Discussion}


The initial draft was prepared using 10 steps of model development according to Dick, Carey, \& Carey (2009), with modifications. Preparation of the initial draft includes: Analysis of Graduates Competency Standards, Core Competencies and Basic Competencies, Identification of Indicators of Competency Achievement, and Formulation of Learning Objectives, Analysis of student characteristics, Analysis of macro and / or micro environments, Determining learning titles and guiding questions, Developing learning strategies, Developing learning strategies, Developing assessment strategies, compile learning implementation plans, develop guidelines, sample student books, and support materials.

The analysis phase of graduate competency standards, core competencies, and basic competencies is carried out to map the essential material of each subject so that the relationships between the material are arranged. Graduate competency standards as competencies to be achieved by graduates, translated into core competencies achieved at the level of the class, and basic competencies related to the material. GPA identification, and formulation of objectives are intended to map the competencies to be achieved by students. This step is important because it guides the teacher in compiling essential material, developed attitudes, and trained skills. The following table provides an example of how this step is carried out.

The step of analyzing student characteristics is done to find out the character of students including the skills they already have that can support the learning process. The output of the analysis of student characteristics is to prepare the supporting materials needed in the learning process. The next step is to analyze the macro and micro environment. The teacher conducts an analysis to find out the macro and / or micro environment that needs the attention of students, both as citizens, citizens, and school residents. The macro environment for elementary school students is an environment that might be accessible, the limitation in this study is the district environment. The micro environment includes the school and / or class environment. The results of the analysis resulted in the formulation of the problem solved by using project-based learning.

The title of learning is determined to provide direction and attraction for students. The title of learning broadly accommodates learning competencies, high-level thinking and 21st century skills. Guiding questions are guidelines for the direction of learning consisting of three levels namely basic questions, learning questions, and content questions. The standard writing of the learning implementation plan uses the terms of learning steps. Learning strategies are formulated in detail including preliminary steps, core activities, and closing activities. The learning model used is a multidisciplinary integrated project-based learning model.

Assessment is carried out on the process and learning outcomes for the realm of students' attitudes, knowledge and skills. Process assessment is intended to ensure that the learning process accommodates the attainment of attitudes, knowledge, and skills. Assessment is carried out on the preparation of students before learning as ensuring the readiness of students to take part in learning; assessment during learning takes place to obtain information on student competencies, also to ensure the project takes place in accordance with the plan; and assessment after the project, namely the assessment is carried out on the product and product publication.

Learning Plans are plans for face-to-face learning activities for one or more meetings. Learning Implementation Plans are developed from syllabus to direct student learning activities in an effort to achieve Basic Competence. Teaching materials are developed by referring to existing teaching materials, competency standards, indicators of achievement of competencies and learning objectives built. Supporting materials are prepared to provide learning resources for students in implementing project-based learning. In addition to covering teaching material, supporting materials also facilitate students in working on learning outcomes. Preparation of supporting materials tailored to the type of activities carried out.

Based on the preliminary study and literature review, an initial draft was produced which produced a learning model and learning tool consisting of guidelines for implementing multidisciplinary integrated project-based learning in elementary schools, including syllabus and plan for implementing learning. The product of the development of multidisciplinary integrated project-based learning models in elementary schools consists of guidebooks and 
student book examples. The student book is an example of development. Teachers can develop themselves using a guidebook. Teachers can develop student books according to themes / topics, and sub-themes / sub-topics, and multidisciplinary project-based learning products themselves in accordance with the basic competencies students will achieve. The results of the Guidance Guidelines by three education experts on each indicator are presented in the following table.

Table 2. Scores of model concept ratings by Experts

\begin{tabular}{clcccc}
\hline \multirow{2}{*}{ No } & \multirow{2}{*}{ Component } & \multicolumn{3}{c}{ Score } & \multirow{2}{*}{ Mean } \\
\cline { 2 - 5 } & Usp. 1 & Exp. 2 & Exp. 3 & \\
\hline 1 & Use good and correct Indonesian & 4 & 4 & 4 & 4 \\
2 & Content is easy to understand & 4 & 4 & 4 & 4 \\
\hline Total & & 8 & 8 & 8 & 8 \\
\hline Percentage of Scores & $80 \%$ & $80 \%$ & $80 \%$ & $80 \%$ \\
\hline
\end{tabular}

Based on table 2 above, the guidebook on aspects of the concept of the model is in the high category. This means that the model concept is already using good and correct Indonesian, and that the content component is easy to understand. With this result, the guidebook from the side of the model concept is ready to be tested.

Table 3. Thematic learning assessment scores in Primary Schools

\begin{tabular}{clcccc}
\hline \multirow{2}{*}{ No } & \multirow{2}{*}{ Component } & \multicolumn{3}{c}{ Score } & \multirow{2}{*}{ Mean } \\
\cline { 2 - 5 } & Use good and correct Indonesian & 4 & 4 & 5 & 4,33 \\
2 & Content is easy to understand & 4 & 4 & 4 & 4,00 \\
\hline Total & 8 & 8 & 9 & 8,33 \\
\hline Percentage of Scores & $80 \%$ & $80 \%$ & $90 \%$ & $83 \%$ \\
\hline
\end{tabular}

The preparation of the guidebook in terms of the thematic learning aspects in primary schools is in a very good category. This means that in the view of experts, the guidance aspect in thematic learning in elementary schools can be understood because it uses good and correct Indonesian. Based on these results, from this aspect the guidebook is ready for use.

Table 4. Assessment of Skills and Curriculum Education scores

\begin{tabular}{clcccc}
\hline \multirow{2}{*}{ No Component } & \multicolumn{3}{c}{ Score } & \multirow{2}{*}{ Mean } \\
\cline { 2 - 5 } & Use good and correct Indonesian & 4 & 4 & 3 & 3,76 \\
2 & Content is easy to understand & 4 & 4 & 4 & 4 \\
\hline Total & & 8 & 8 & 7 & 7,76 \\
\hline Percentage of Scores & $80 \%$ & $80 \%$ & $80 \%$ & $78 \%$ \\
\hline
\end{tabular}

Aspects of skills education developed and curriculum in primary schools are in the high category. But there is still one component that needs improvement and improvement so that it can be more easily understood. The use of Indonesian language needs to be studied further so that the use of Indonesian can be better. However, this aspect can already be used in multidisciplinary integrated project-based learning.

Model aspects are in the very good category. It means that the model is easy to understand and easy to implement. This convenience is supported by the adequacy of information in implementing multidisciplinary integrated project-based learning models. 
Table 5. Model assessment scores

\begin{tabular}{clcccc}
\hline \multirow{2}{*}{ No } & Component & \multicolumn{3}{c}{ Score } & \multirow{2}{*}{ Mean } \\
\cline { 3 - 5 } & Easy to understand model & 4 & 4 & 5 & 4,33 \\
2 & The model is easy to implement & 4 & 4 & 4 & 4 \\
3 & Sufficient information to implement the model & 4 & 4 & 4 & 4 \\
\hline Total & 12 & 12 & 13 & 12,33 \\
\hline Percentage of Scores & $80 \%$ & $80 \%$ & $87 \%$ & $82 \%$ \\
\hline
\end{tabular}

Table 6. Scoring scores for presenting manuals

\begin{tabular}{clcccc}
\hline \multirow{2}{*}{ No } & Component & \multicolumn{3}{c}{ Score } & \multirow{2}{*}{ Mean } \\
\cline { 2 - 5 } & Exp. 1 & Exp. 1 & Exp. 1 & \\
\hline 1 & Logical presentation & 4 & 4 & 5 & 4,33 \\
2 & Creed concept & 4 & 4 & 5 & 4,33 \\
3 & Substance balance & 4 & 4 & 4 & 4,00 \\
4 & Create interactive communication and generate & 3 & 4 & 3 & 3,33 \\
5 & feedback for self-evaluation & 4 & 4 & 4 & 4,00 \\
\hline Total & Product Clarity & 19 & 20 & 21 & 20 \\
\hline Percentage of Scores & $76 \%$ & $80 \%$ & $84 \%$ & $80 \%$ \\
\hline
\end{tabular}

The presentation of guidebooks is in the high category. This means that the book has been presented or designed from the side of the contents of the book can be easily understood. Presentation of a logical guidebook, the concept presented is coherent. The substance of the component model is balanced, and the product produced is clear. Components that need to be improved from the aspect of presentation are manuals that can create interactive communication and generate feedback for self-evaluation.

Table 7. Score assessment of language aspects of the guidebook

\begin{tabular}{clcccc}
\hline \multirow{2}{*}{ No } & Component & \multicolumn{3}{c}{ Score } & \multirow{2}{*}{ Mean } \\
\cline { 2 - 5 } & Exp. 1 & Exp. 1 & Exp. 1 & 4,33 \\
2 & Language is easy to understand & 4 & 4 & 5 & 4,330 \\
3 & In accordance with the level of development of & 4 & 4 & 4 & 4,00 \\
4 & students & 4 & 3 & 4 & 3,67 \\
5 & Encouragement of critical thinking in students & 4 & 4 & 4 & 4,00 \\
6 & The grooves of thought flow & 4 & 4 & 4 & 4,00 \\
7 & Integrity of meaning & 4 & 4 & 4 & 4,00 \\
\hline Total & 4 & 4 & 4 & 4,00 \\
\hline Percentage of Scorms and symbols & 28 & 27 & 29 & 28 \\
\hline
\end{tabular}

Language aspects used in the guidebook are in the high category. However, it is necessary to improve the components of conformity with the level of development of students.

The graphic aspects of guidebooks are in the very high category. The overall validation of aspects of the guidebook shows that the percentage of the guidebook scores from all aspects is $80 \%$ or in the high category. Improving the quality of the model manual is done by paying attention to the advice and recommendations provided by experts.

Some notes of improvement submitted by experts are as follows: 1) the use of the term / designation to be consistent: students, learners, students ?; 2) Some typing is improved; 3) inadequate study of student characteristics; 4) page 41: "grouping students who have the same character" why? Need to be repaired; 5) Are teachers not given the opportunity to modify the implementation of learning? The reason, often the implementation of learning is very situational; 6) aspects that need to be assessed in the learning assessment process should be added to the observation of the suitability of learning activities to achieve the objectives; 7 ) analysis of student characteristics, not so clear, student characteristics based on age and developmental psychology to make it more visible; 8) the size of the book is better reduced by 
about $2 \mathrm{~cm}$, so that it looks more harmonious like textbooks in general; 7) use Indonesian language that is interactive with the words "you", or "we"; 8) this design needs to be written consistently including paragraft writing, at least each paragraph consists of 3 sentences up to 15 lines; 9) all writings citing other sources include references.

Table 8. Scoring scores on the graphic aspects of the guidebook

\begin{tabular}{clcccc}
\hline \multirow{2}{*}{ No Component } & \multicolumn{3}{c}{ Score } & \multirow{2}{*}{ Mean } \\
\cline { 2 - 4 } & Exp. 1 & Exp. 1 & Exp. 1 & \\
\hline 1 & Book size & 4 & 3 & 5 & 4,00 \\
2 & pearance of cover composition & 4 & 4 & 5 & 4,33 \\
3 & Font on the cover & 4 & 4 & 5 & 4,33 \\
4 & Font size on the cover & 4 & 4 & 5 & 4,33 \\
5 & Illustration on the cover & 4 & 4 & 4 & 4,00 \\
6 & Content design & 3 & 4 & 3 & 3,33 \\
7 & $\begin{array}{l}\text { Content illustration can support the achievement } \\
\text { of competence }\end{array}$ & 4 & 4 & 4 & 4,00 \\
8 & Illustration information can clarify the purpose of & 3 & 4 & 4 & 3,67 \\
9 & the illustration & 4 & 4 & 4 & 4,00 \\
10 & Fonts in the contents section & 4 & 4 & 5 & 4,33 \\
11 & Cont size in the contents section & & 4 & \\
& contents of the book & 3 & 4 & 5 & 4,00 \\
\hline Total and illustrations on the & & 41 & 43 & 49 & 44,33 \\
\hline Percentage of Scores & $75 \%$ & $78 \%$ & $89 \%$ & $81 \%$ \\
\hline
\end{tabular}

Based on the recommendations and recommendations, and added with an overall analysis of aspects of the guidebook, it shows that the percentage of the guidebook scores from all aspects is $80 \%$ or in the high category. Improvements are made to develop guidelines to be more easily understood and the implementation steps are easier to implement.

The addition of a study of student characteristics is done by providing the following additions: Sardiman (2011) about the characteristics of students divided into three types; Budiningsih (2017) regards the characteristics of students that influence the process and learning outcomes, namely intelligence, initial ability, cognitive style, learning style, motivation, socio-cultural, emotional development, and social development; Andi Prastowo (2014) distinguishes student characteristics into two, namely developments in physical aspects and development in mental aspects. The development of physical aspects of students is mature and can control themselves and their balance. In the mental aspects include intellectual, language, social, emotional, and religious moral development. The results of validating student book examples in each aspect are as follows:

Table 10. Scoring scores on Student's content / material sample material by Experts

\begin{tabular}{clcccc}
\hline \multirow{2}{*}{ No } & Component & \multicolumn{3}{c}{ Score } & Mean \\
\cline { 3 - 5 } & Material extent according to KD 3 & Exp. 1 & Exp. 1 & Exp. 1 & \\
\hline 1 & Depth of material according to KD 3 & 4 & 4 & 4 & 4,00 \\
2 & 4 & 4 & 4 & 4,00 \\
3 & Accuracy of facts & 4 & 4 & 5 & 4,33 \\
4 & Concept / legal / theory accuracy & 4 & 4 & 5 & 4,33 \\
5 & Accuracy of Procedure / Method & 4 & 4 & 4 & 4,00 \\
6 & Recency / Feature Integrity & 4 & 4 & 5 & 4,33 \\
7 & Presenting concrete examples from the local / & 4 & 4 & 5 & 4,33 \\
\hline Total & national / regional / international environment & 28 & 28 & 32 & 29,33 \\
\hline Percentage of Scores & $80 \%$ & $80 \%$ & $91 \%$ & $84 \%$ \\
\hline
\end{tabular}

The percentage of the Content / Material aspect score is $84 \%$ or in the Very High category. This means that from the aspect of content / material, the sample student book is ready to be used. 
The percentage score for presentation aspects is $80 \%$ or in the High category. This means that from the aspect of presentation, the sample student book is ready to be used in trials in the PBPTM. But in terms of items individually, three things that must be corrected are the motivational component at the beginning of the chapter, and create effective communication and generate feedback for self-evaluation.

Table 11. Scoring scores on aspects of the presentation of Student book examples by Experts

\begin{tabular}{clcccc}
\hline \multirow{2}{*}{ No } & Component & \multicolumn{3}{c}{ Score } & Mean \\
\cline { 3 - 5 } & Exp. 1 & Exp. 1 & Exp. 1 & \\
\hline 1 & Logical presentation & 4 & 4 & 5 & 4,33 \\
2 & Conceptual wreckage & 4 & 4 & 4 & 4,00 \\
3 & Substance balance & 4 & 4 & 4 & 4,00 \\
4 & Suitability and accuracy of illustrations and material & 4 & 4 & 4 & 4,00 \\
5 & Advance organizer at the beginning of the chapter & 4 & 4 & 3 & 3,67 \\
6 & Active involvement of students and student- & 4 & 4 & 4 & 4,00 \\
& centered & & & & \\
7 & Create interactive communication and generate & 4 & 4 & 3 & 3,67 \\
8 & feedback for self-evaluation & 4 & 4 & 5 & 4,33 \\
\hline Potal & Product Clarity & 32 & 32 & 32 & 32 \\
\hline Percentage of Scores & $80 \%$ & $80 \%$ & $80 \%$ & $80 \%$ \\
\hline
\end{tabular}

Table 12. Scoring scores for language aspects of sample Student books by Experts

\begin{tabular}{rlcccc}
\hline \multirow{2}{*}{ No } & \multirow{2}{*}{ Component } & \multicolumn{3}{c}{ Score } & \multirow{2}{*}{ Mean } \\
\cline { 2 - 5 } & Using standard Indonesian & 4 & 4 & 4 & 4,00 \\
2 & Language is easy to understand & 4 & 4 & 4 & 4,00 \\
3 & In accordance with the level of development of & 4 & 4 & 4 & 4,00 \\
4 & students & 4 & 4 & 5 & 4,33 \\
5 & Encouragement of critical thinking in students & 4 & 4 & 5 & 4,33 \\
6 & The grooves of thought flow & 4 & 4 & 4 & 4,00 \\
7 & Untegrity of meaning & 4 & 4 & 4 & 4,00 \\
\hline Total terms and symbols & 28 & 28 & 30 & 28,67 \\
\hline Percentage of Scores & $80 \%$ & $80 \%$ & $86 \%$ & $82 \%$ \\
\hline
\end{tabular}

The percentage of language aspect scores is $82 \%$ or in the Very High category. This means that from the aspect of language, examples of student books are ready to be used in trials in the PBPTM. The percentage score for graphic aspects is $76 \%$ or in the High category. This means that from the graphic aspect, the sample student book is ready to be used in trials in the PBPTM.

Overall, the student book sample is quite good. Improvements are made by paying attention to suggestions. Some suggestions and recommendations given by the assessor are as follows: 1) correct according to suggestions (oral); 2) there is no / clear allocation of teaching materials intended for what grade elementary school students or for large elementary / elementary school students; 3 ) The size of the book is better reduced by about $2 \mathrm{~cm}$; 4 ) it is necessary to add learning motivation that is relevant to the material and easy to do in a short time; 5) interactive communication uses simple language and single sentence structure; 6) provide rewards for student efforts; 7 ) content design needs to be made more consistent both concerning type, font size and spacing between lines and between words; 8 ) all images quoting from other sources must be mentioned as sources. 
Table 13. Scores for the assessment of the graphic aspects of Student samples by Experts

\begin{tabular}{|c|c|c|c|c|c|}
\hline \multirow{2}{*}{ No } & \multirow{2}{*}{ Component } & \multicolumn{3}{|c|}{ Score } & \multirow{2}{*}{ Mean } \\
\hline & & Exp. 1 & Exp. 1 & Exp. 1 & \\
\hline 1 & Book size & 3 & 3 & 5 & 3,67 \\
\hline 2 & pearance of cover composition & 4 & 4 & 5 & 4,33 \\
\hline 3 & Font on the cover & 3 & 4 & 5 & 4,00 \\
\hline 4 & Font size on the cover & 3 & 4 & 5 & 4,00 \\
\hline 5 & Illustration on the cover & 4 & 4 & 4 & 4,00 \\
\hline 6 & Content design & 4 & 4 & 3 & 3,67 \\
\hline 7 & $\begin{array}{l}\text { Content illustration can support the achievement of } \\
\text { competence }\end{array}$ & 3 & 4 & 4 & 3,67 \\
\hline 8 & $\begin{array}{l}\text { Illustration information can clarify the purpose of } \\
\text { the illustration }\end{array}$ & 4 & 4 & 4 & 4,00 \\
\hline 9 & Fonts in the contents section & 3 & 4 & 3 & 3,33 \\
\hline 10 & Font size in the contents section & 3 & 4 & 3 & 3,33 \\
\hline 11 & $\begin{array}{l}\text { Color design, letters, and illustrations on the } \\
\text { contents of the book }\end{array}$ & 4 & 4 & 3 & 3,67 \\
\hline Total & & 38 & 43 & 44 & 41,67 \\
\hline Perce & ntage of Scores & $69 \%$ & $78 \%$ & $80 \%$ & $76 \%$ \\
\hline
\end{tabular}

\section{Conclusions and Suggestions}

Based on the results of research and discussion it can be concluded that the multidisciplinary integrated project-based learning model to improve critical thinking skills and student collaboration with derivative products in the form of learning manuals and student book examples can be used in the learning process in elementary school.

Suggestions conveyed relating to the results of this development are necessary steps of caution and choosing basic competencies and subject matter. When the teacher combines the material in a learning using a multidisciplinary integrated project-based learning model, a study of the links between the material needs to be done.

\section{References}

Adri, \& Istyawati, I. (2013). Pengaruh model pembelajaran berbasis proyek terhadap tingkat kerjasama siswa dan hasil belajar siswa kelas X TPM pada mata pelajaran menggambar di SMKN 1 Jetis Mojokerto. JPTM, 01(02), 28-37.

Adyarta, K. D., Hartono, M., \& Pramono, H. (2012). Penerapan permainan bola voli mini terhadap pembentukan aspek kerjasama siswa kelas IV SD. Journal of Physical Education, Sport, Health and Recreation, 1(2), 57-60. doi:10.15294/active.v1i2.426

Afrilianto, M. (2012). Peningkatan pemahaman konsep dan kompetensi strategis matematis siswa SMP dengan pendekatan metaphorical thinking. Jurnal IImiah Program Studi Matematika STKIP Siliwangi Bandung, 1(2), 192-202.

Alghamdi, A. K. (2017). The effects of an integrated curriculum on student achievement in Saudi Arabia. EURASIA Journal of Mathematics Science and Technology Education, 13(9), 9-6100. doi:10.12973/eurasia.2017.01051a

Asmawati, E. Y. (2015). Lembar kerja siswa (LKS) menggunakan model guided inquiry untuk meningkatkan keterampilan berpikir kritis dan penguasaan konsep siswa. Jurnal Pendidikan Fisika, III(2), 1-16. doi: 10.24127/jpf.v3i1.13

Astriyandi, A., Chotimah, U., \& Faisal, E. E. (2016). Kemampuan guru menerapkan penilaian autentik dalam pembelajaran PPKn (studi kasus di SMA Negeri 1 Indralaya). Jurnal Bhinneka Tunggal Ika, 3(2), 187-198.

Boyles, T., \& College , M. (2012). 21st century knowledge, skills, and abilities and entrepreneurial competencies: A model for undergraduate entrepreneurship education. Journal of Entrepreneurship Education, 15, 41-55.

Child, S., \& Shaw, S. (2016). Collaboration in the 21st century: Implications for assessment. Research Matters, 22, 17-22.

Dick, W., Carey, L., \& Carey, J. O. (2009). The Systematic Design of Instruction. Merrill: Pearson. 
Effendi, M. (2017). Pembelajaran berbasis proyek (PjBL) untuk mengembangkan kemampuan berpikir kritis mahasiswa PGMI IAIN Ponorogo. Cendekia, 15(2), 305-317.

Fatimah, S. (2018). The effect of project based science learning on pgsd students' creative thinking ability. Jurnal Pendidikan Indonesia, 7(2), 100-105. doi:10.23887/jpiundiksha.v7i2.13018

Gall, M. D., Gall, J. P., \& Borg, W. R. (2007). Educational Research. Boston: Pearson Education.

Haeruman, L. D., Rahayu , W., \& Ambarwati, L. (2017). Pengaruh model discovery learning terhadap peningkatan kemampuan berpikir kritis matematis dan self-confidence ditinjau dari kemampuan awal matematis siswa SMA di Bogor Timur. Jurnal Penelitian dan Pembelajaran Matematika, 10(2), 157-168. doi:10.30870/jppm.v10i2.2040

Hapsari , N. S., \& Yonata, B. (2014). Keterampilan kerjasama saat diskusi kelompok siswa kelas XI IPA pada materi asam basa melalui penerapan model pembelajaran kooperatif di SMA Kemala Bhayangkari 1 Surabaya. Unesa Journal of Chemical Education, 3(2), 181-188.

Haryani, D. (2011). Pembiasaan berpikir kritis dalam belajar matematika sebagai upaya pembentukan individu yang kritis. Seminar Nasional Penelitian, Pendidikan dan Penerapan $M$ (pp. 127-132). Yogyakarta: Fakultas MIPA, Universitas Negeri Yogyakarta.

Helmane, I., \& Briska, I. (2017). What is developing integrated or interdisciplinary or multidisciplinary or transdisciplinary education in School? Signum Temporis, 9(1), 7-15. doi:10.1515/sigtem-2017-0010

Indrawatiningsih, N. (2018). Arguments in Critical Thinking Ability. First International Conference on Science, Mathematics, and Education, (ICOMSE 2017) (pp. 12-15). Malang: Atlantis Press.

Insyasiska, D., Zubaidah, S., \& Susilo, H. (2015). Pengaruh project based learning terhadap motivasi belajar, kreativitas, kemampuan berpikir kritis, dan kemampuan kognitif siswa pada pembelajaran biologi. Jurnal Pendidikan Biologi, 7(1), 9-21.

Jamaludin, D. N. (2017). Pengaruh pembelajaran berbasis proyek terhadap kemampuan berpikir kritis dan sikap ilmiah pada materi tumbuhan biji. GENETIKA (Jurnal Tadris Biologi), 1(1), 18-41.

Karakoc, M. (2016). The significance of critical thinking ability in terms of education. International Journal of Humanities and Social Science, 6(7), 81-84.

Khasanah, M. M., Pangestu, A. B., Intantiasari, Shella, N. H., Susanti, F., \& Prayitno, B. A. (2018). Profil keterampilan kerjasama Siswa Kelas VII di salah satu SMP Swasta di Magelang. Jurnal Pendidikan Biologi, 7(2), 132 - 140. doi:10.24114/jpb.v7i2.10050

Kusmanto, H., \& Marliyana, I. (2014). Pengaruh Pemahaman Matematika Terhadap Kemampuan Koneksi Matematika Siswa Kelas VII Semester Genap SMP Negeri 2 Kasokandel Kabupaten Majalengka. EduMa, 3(2), 61-75.

Lestari, K. S., Suarni, N. K., \& Antara, P. A. (2016). Pengaruh model pembelajaran berbasis proyek terhadap kemampuan kerjasama anak usia 5-6. e-Journal Pendidikan Anak Usia Dini Universitas Pendidikan Ganesha, 4(2), -.

Lipursari, A. (2013). Peran sistem informasi manajemen (SIM) dalam pengambilan keputusan. Jurnal STIE Semarang, 5(1), 26-37.

Miftari, I. (2014). Project based learning: Developing 21st Century collaborative and technology skills. European Journal of Research on Education, Special Issue: Educational Technology and Lifelong Learning, 52-57.

Murfiah, U. (2017). Model pembelajaran terpadu di Sekolah Dasar. Jurnal Pesona Dasar, 1(5), 57-69.

Nahdi, D. S. (2015). Meningkatkan kemampuan berpikir kritis dan penalaran matematis siswa melalui model brain based learning. Jurnal Cakrawala Pendas, 1(1), 13-22.

Puspita, A. T., \& Jatmiko, B. (2013). Implementasi model pembelajaran inkuiri terbimbing (guided inquiry) terhadap keterampilan berpikir kritis siswa pada pembelajaran fisika materi fluida statis kelas XI di SMA Negeri 2 Sidoarjo. Jurnal Inovasi Pendidikan Fisika, 2(3), 121-125. 
Quint , J., \& Condliffe , B. (2018). Project-based learning a promising approach to improving student outcomes. Issue Focus, 1-2.

Rachmawati , I., Feranie, S., Sinaga, P., \& Saepuzaman , D. (2018). Penerapan pembelajaran berbasis proyek untuk meningkatkan keterampilan berpikir kreatif ilmiah dan berpikir kritis ilmiah siswa SMA pada materi kesetimbangan benda tegar . Jurnal Wahana Pendidikan Fisika, 3(2), 25-30.

Rachmawati, R. I. (2018). Pengaruh penerapan metode problem solving dan metode group investigation terhadap kemampuan berpikir kritis siswa dilihat dari kemampuan awal. Indonesian Journal of Economics Education, 1(1), 85-102.

Rati, N. W., Kusmaryatni, N., \& Rediani, N. (2017). Model pembelajaran berbasis proyek, kreativitas dan hasil belajar mahasiswa. Jurnal Pendidikan Indonesia, 6(1), 60-71.

Rosita, I., \& Leonard. (2013). Meningkatkan kerja sama siswa melalui pembelajaran kooperatif tipe think pair share. Jurnal Formatif, 3(1), 1-10. doi:10.30998/formatif.v3i1.108

Sardiman, A. M. (2011). Interaksi dan motivasi belajar mengajar. Jakarta: Rajawali Pers.

Serrat, O. (2010). Critical thinking. Washington, DC: Asian Development Bank.

Siripho, T. (2012, Desember 12). Kompas, p. 12.

Snyder, L. G., \& Snyder, M. J. (2008). Teaching critical thinking and problem solving skills. The Delta Pi Epsilon Journal, 1(2), 90-99.

Subagia, I. W., \& Wiratma, I. L. (2016). Profil penilaian hasil belajar siswa berdasarkan kurikulum 2013. Jurnal Pendidikan Indonesia, 5(1), 39-54.

Suhardi. (2013). Peningkatan partisipasi dan kerjasama Siswa menggunakan model kooperatif tipe Jigsaw pada materi protozoa kelas X SMA N Pengasih. Jurnal Pendidikan Matematika dan Sains, 1(2), 140-146.

Susilowati, Sajidan, \& Ramli, M. (2017). Analisis keterampilan berpikir kritis siswa madrasah aliyah negeri di kabupaten magetan. Seminar Nasional Pendidikan Sains "Strategi Pengembangan Pembelajaran dan Penelitian Sains untuk Mengasah Keterampilan Abad 21 (Creativity and Innovation, Critical Thinking and Problem Solving, Communication, Collaboration/4C) " (pp. 223-231). Surakarta: Universitas Sebelas Maret.

Wang, Y., Lavonen , J., \& Tirri , K. (2018). Aims for learning 21st century competencies in national primary science curricula in China and Finland. EURASIA Journal of Mathematics, Science and Technology Education, 14(6), 2081-2095.

Yulianti, S. D., Djatmika, E. T., \& Santoso, A. (2016). Pendidikan karakter kerja sama dalam pembelajaran siswa sekolah dasar pada kurikulum 2013. Jurnal Teori dan Praksis Pembelajaran IPS, 1(1), 33-38.

Zuhera, Y., Habibah,, S., \& Mislinawati. (2017). Kendala guru dalam memberikan penilaian terhadap sikap siswa dalam proses pembelajaran berdasarkan kurikulum 2013 di SD Negeri 14 Banda Aceh. Jurnal IImiah Pendidikan Guru Sekolah Dasar, 2(1), 73-87. 